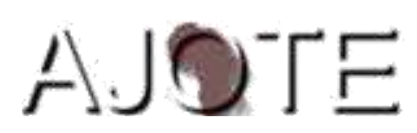

African Journal of Teacher Education

ISSN 1916-7822. A Journal of Spread Corporation

Volume $92020 \quad$ Pages $140-151$

\title{
Utilization of Information Communication Technologies in Effective Administration of Secondary Schools in Mitooma District of Uganda
}

\author{
Aheisibwe Irene $^{1} \&$ Byamukama Muramuzi Sprito $^{2}$ \\ Department of Foundations of Education \\ Faculty of Education \\ ${ }^{1}$ Kabale University, Uganda \\ ${ }^{2}$ Bishop Stuart University, Mbarara, Uganda
}

\begin{abstract}
The study aimed at assessing the utilization of Information Communication Technologies in the effective administration of secondary schools in Mitooma district, Uganda. A cross-sectional survey design was employed. Data was collected using a closed-ended questionnaire developed by Özdemir et al. (2014) and an interview guide. Statistical Package for Social Scientists software version 23.0 was used to analyze the data. The study revealed a lack of knowledge and skills of ICT, limited electricity supply, poor quality computers, and inadequacy of computer accessories as reasons for the non-utilization of ICT.
\end{abstract}

Keywords: Information Communication Technologies, Effective Administration, Mitooma

District of Uganda

\section{Introduction}

Background to the Study

The use of Information Communication Technology (ICT) in the administration of schools has gained popularity globally over the past 20 years and this has led to changes in the way schools are administered (Kayiwa, Raihan, \& Clement, 2016). ICT has led to changes not only to the teaching and learning process but also in the management and administration of educational institutions. Information Communication Technology emphasis is one of the strategies increasingly adopted in 
recent times by governments around the world to encourage economic development (Gupta, Dasgupta \& Gupta, 2008). Oboegbulem and Ugwu (2013) Observe that the use of ICT in African schools can ease student recruitment and records management and can improve the quality of the teaching-learning process. In order to achieve Sustainable Development Goal 4 i.e. provision of quality education, Uganda has adopted ICT as one of the strategies (Muyinda, Mayende, Maiga, \& Oyo, 2019). However, most Ugandan secondary schools have not adopted ICT in running daily school activities (Muyinda, Mayende, Maiga, \& Oyo, 2019). Many secondary schools in Mitooma district still use papers, pens, pencils, and folder files for record-keeping despite the supply of 13 computers to each government-aided secondary school by the government of Uganda in 2013. This has led to difficulties in monitoring the teaching-learning process, to delays in the processing of students' progress reports, and wastage of government resources.

Conceptually, this study was based on two variables namely; information communication technology and effective administration. Information communication technology is a diverse set of technological tools and resources used to communicate, create, disseminate, store, and manage information (Sharma, 2019). These technological tools include laptops and computers, the internet, mobile technology, iPads, digital television, palmtops, iPods, and digital cameras/videos (Freeman \& Hasnaoui, 2010). Effective administration, on the other hand, is the link between an organization's various departments and the smooth flow of information from one unit to another (Adebayo, 2013). This study conceptualized effective administration as planning, organizing, and controlling school activities using Information Communication Technology.

This study was guided by the sociotechnical theory (STS) proposed by Eric Trist, Ken Bamforth and Fred Emery which suggests that, rather than simply putting people into existing technical systems, work places should be designed in such a way that both people and technology coexist in harmony (Walker, Stanton, Salmon, \& Jenkins, 2008). It is widely acknowledged that adopting a socio-technical approach leads to systems that are more acceptable to end users and deliver better value to stakeholders. This theory was used because it investigates computersupported cooperative work and cognitive systems that bridge the gap between traditional and modern means of data storage. Figure 1. Below explains how the sociotechnical approach works;

Figure 1: Sociotechnical theory diagrammatic view. Source: Robert and Stephen (1977) AJOTE Vol. 9 (2020), pp. 140 - 151 


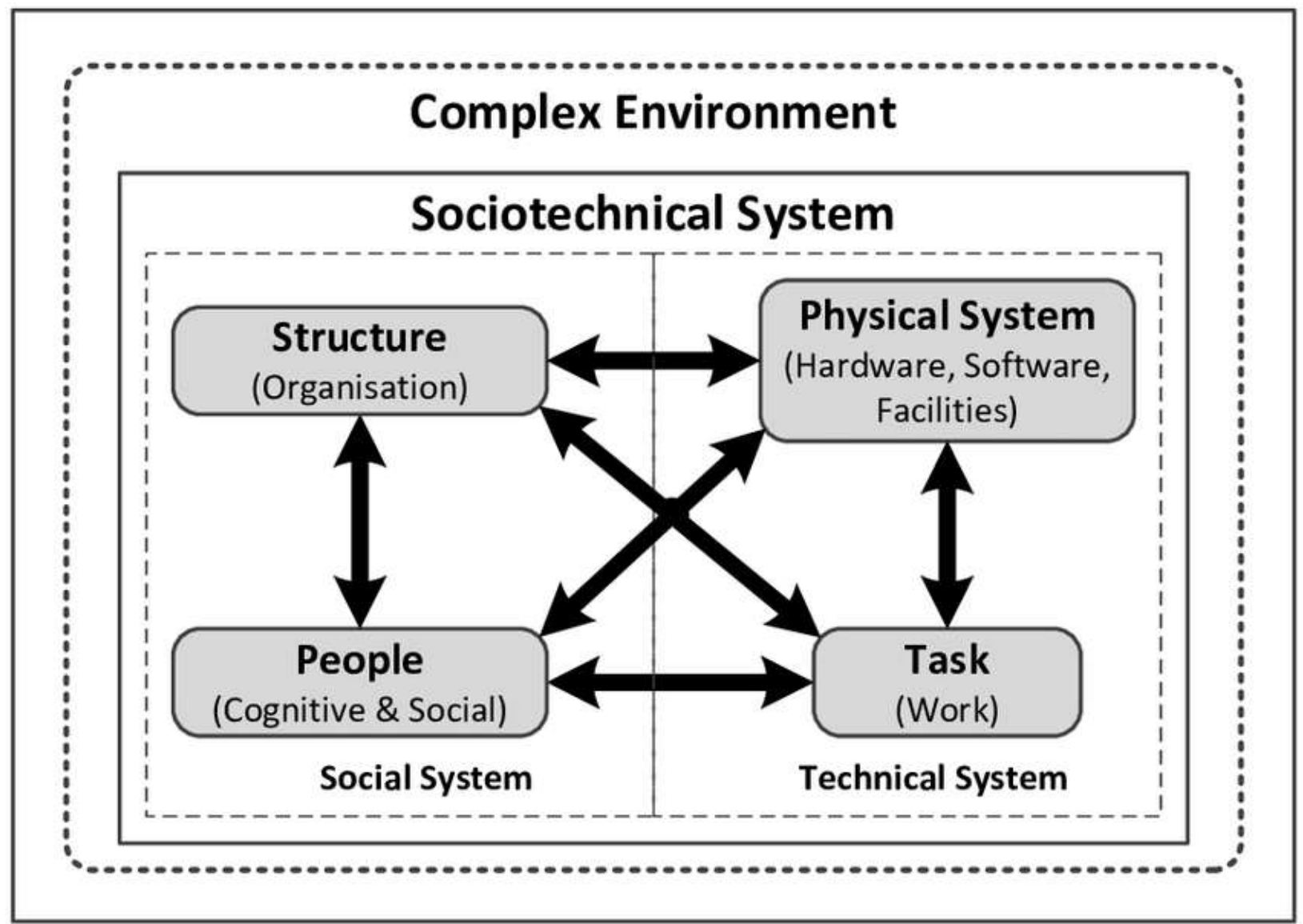

\section{Statement of the Problem}

Mitooma district secondary schools continue to use stationery for their record manage despite government provision of some computers to the since 2013 (Asiimwe \& Byensi, 2017). The difficulties in the proper management and monitoring of the teaching-learning process that this had produced is the background and justification for this study. We sought to examine the specific nature of links between the use or non-use of ICT facilities and efficiency in school management and outcomes.

\section{Research Question}

What is the relationship between ICT utilization and effective administration of secondary schools in Mitooma district of Uganda? 


\section{Methodology}

\section{Research Design}

This study adopted across sectional survey design because it provides a description of trends and attitudes or opinions of a population and it allows generalisation from a sample to an entire population so that inferences can be made about some characteristics, attitude or behaviour of that population (Tashakkori \& Creswell, 2009). With a cross sectional survey design, it is easier to study a larger population from a small group of individuals and data can be collected at specific points in time; it is therefore cost effective (Creswell, 2007).

\section{Study Population \& Sample Size}

The study population constituted secondary school headteachers as well as teachers in Mitooma District. There are ten (10) government-aided secondary schools in Mitooma district with 350 teachers and 10 head teachers (District Education Department of Mitooma District, 2019). A total of 196 teachers and headteachers participated in the study guided by Morgan and Krecjie's table of sample size determination.

\section{Sampling Techniques}

The study employed both purposive and simple random techniques. A total population purposive sampling technique was used to select headteachers. Creswell (2007) suggested that total population purposive sampling technique is used where the size of the population that has a particular set of characteristics that one is interested in is very small. Purposive sampling was also used because it is time and cost-effective. To select teachers, simple random sampling was used because it offers an equal chance of selection, it is easier to form representative groups from an overall population and provides information with a lower chance of data errors. (Kombo \& Tromp, 2006).

\section{Data Collection Instruments}

The study employed a mixed methodological philosophy where both quantitative approach in the form of questionnaires and qualitative approach inform of in-depth interviews were employed during the data collection. Teachers responded to the questionnaire while the headteachers were 
interviewed. A closed-ended questionnaire developed by Özdemir et al. (2014) was used to collect data from teachers. This questionnaire comprised three sections namely; Section A which addressed the socio-demographic characteristics, section B which contained closed-ended items on a 5-point Likert scale ranging from strongly agree to strongly disagree examining the relationship between ICT utilization and effective administration and section $\mathrm{C}$ which contained open-ended items addressing non-utilization of ICT. A structured interview guide was also used to interview the headteachers. The items were mainly open-ended, thus giving headteachers the opportunity to provide in-depth knowledge about utilization of ICT for effective administration. The interviews also helped to crosscheck, verify and strengthen some of the data gathered from the teachers' questionnaire.

\section{Quality Control}

Pilot testing was done to ensure validity and reliability of the questionnaire (Nassaji, 2015). The instruments were pre-tested in one government-aided secondary school in Mitooma district. Cronbach's Coefficient alpha, which requires only a single test to determine the internal consistency of instruments, was computed. The instruments obtained a Cronbach alpha of 0.82. This deemed it fit for data collection.

\section{Procedure}

A letter of introduction obtained from District Education Officer (DEO) was presented and the purpose of the study clearly explained to participants who thereafter signed consent forms. Participation was voluntary and respondents were free to withdraw from the study at any point without reprimand. The identities of the respondents were kept confidential throughout the study. Appointments were scheduled and questionnaires distributed. The tools of data collection were later collected from respondents at an agreed time. After filling the tools, they were kept confidential, accessible only to the researchers.

\section{Data Management and Analysis}

Data management is part of the research process which aims at making the research process as efficient as possible. To ensure efficient organisation of data beginning with its inputting into the computer, completely filled instruments were screened, coded and entered into the Statistical Package for Social Scientists (SPSS) version 23.0.Descriptive statistics i.e. frequencies and 
percentages were computed for socio-demographic characteristics to examine the relationship between ICT utilisation and effective administration Pearson product moment correlation coefficient was computed while thematic analysis was done to establish reasons for non-utilisation of ICT in secondary schools of Mitooma district.

\section{Findings}

Table 1. Socio-demographic Characteristics of Respondents in Mitooma District

\begin{tabular}{llll}
\hline Characteristics & & Frequency & Percent \\
\hline Age (Years) & 20-30 years & 72 & 36.7 \\
& 31-40 years & 91 & 46.6 \\
& 41-50 years & 31 & 15.8 \\
& Above 50 years & 2 & 1.0 \\
Gender & Male & 141 & 71.9 \\
& Female & 55 & 28.1 \\
Period spent in & 1-2 years & 70 & 35.7 \\
school & 3-5 years & 49 & 25.0 \\
& 6-10 years & 47 & 24.0 \\
& above 10 years & 30 & 15.3 \\
Experience (years) & 1-2 years & 55 & 28.1 \\
& 3-5 years & 40 & 20.4 \\
& 6-10 years & 32 & 16.3 \\
& Above 10 years & 69 & 35.2 \\
\hline
\end{tabular}

Source: Primary Data, 2019. 
Table 1 shows that the study was comprised of mainly males (71.9\%) who were between 31-40 years $(46.4 \%)$. The majority of the participants $(35.7 \%)$ had spent $1-2$ years teaching in that school but with a teaching experience of above ten years (35.2\%).

Table 2. Level of Head Teachers' ICT Utilization in Secondary Schools in Mitooma District

\begin{tabular}{lccc}
\hline Status & Range & Frequency & Percent \\
\hline Low & $10-22$ & 103 & 52.6 \\
Average & $23-35$ & 68 & 34.7 \\
High & $36-48$ & 25 & 12.8 \\
\hline Total & & $\mathbf{1 9 6}$ & $\mathbf{1 0 0 . 0}$ \\
\hline
\end{tabular}

Table 2 above shows that the majority (52\%) headteachers of secondary schools in Mitooma district have low usage of ICT followed by $(34.7 \%)$ while $(12.8 \%)$ of respondents indicated high usage of ICT. From the above table, majority headteachers have not embraced ICT for effective administration. Through an interview, the following reasons were identified;

Lack of knowledge of how to use ICT was reported as the major hindrance. One headteacher said;

Computers were distributed to schools but there were no efforts on training us how to use them. We have not had workshops on practical skills of ICT. Generally, most teachers in Uganda have little ICT training, either in general computer skills or knowledge of how to use computers pedagogically.

Another issue raised was the quality and capability of computers available in secondary schools. One teacher said;

Most Computers are so old and slow in processing information. In this school, many computers are aged with software problems and have virus.

Power source/supply also challenged most secondary schools in ICT utilization. Mitooma District has irregular electricity as reflected in a statement by one head teacher; 
Sometimes electricity is off for weeks yet school activities must go on. This makes me reluctant on ICT usage. I would rather keep using my paper and pen since they don't require electricity to operate.

Limited access to computers and their accessories also limits the utilization of ICT in Mitooma secondary schools. Most respondents reported that there were few computers in schools and they didn't have personal computers. The few available computers were desktop which had to be used only at school premises which consequently limits ICT usage.

\section{Discussion, Conclusion and Recommendations}

The study established that most secondary schools in Mitooma district do not effectively utilise ICT in administration. This is in agreement with Montoya et al. (2011) who noted that most school administrators lacked ICT knowledge and skills thus hindering ICT usage. Similarly, Ghani et al. (2011) suggested that most administrators lack knowledge of how information communication technologies can support their daily activities such as student administration, staff administration and general administration. This study also agrees with Peralta and Costa (2007) who conducted a qualitative multiple case-study research on school principals' usage of ICT in effective administration in five European countries. Their study reveals that that technical competence influenced the usage of ICT in administration. However, a study in Portugal, regarding school principals' usage of ICT in effective administration reported that ICT usage was dependent on age whereby younger school administrators are associated with technical competence and pedagogical efficiency while using ICT.

The study revealed that Ugandan teachers in Mitooma district did not receive any training on ICT usage. This is in agreement with a study by Egomo., Enyi and Tah (2012) who suggested that although ICT was introduced in schools, there were no efforts to induct teachers and administrators into its effective use. This finding also agrees with a study by Novatech (2008) in Burundi which suggested lack of awareness, coupled with a lack of trained teachers with ICT knowledge leading to lack of interest and seeming lethargy in ICT usage in secondary schools.

Power source/supply also challenged most secondary schools in ICT utilization. This finding agrees with a study by Novatech (2008) in Burundi which suggested that infrastructure 
particularly electricity has been the major threat to the growth of that country's ICT sector. This finding agrees with a study conducted by Adedeji (2011) in Nigeria who cited irregular supply of electricity as a major hindrance to ICT usage among school administrators.) Shafika (2007) further states that ICT utilization in school administration in Zambia is affected by irregular electricity.

Limited access to computers and their accessories was mentioned as a major hindrance to ICT usage in effective administration. ICT access is a necessary condition to the integration of ICT in education (Plomp, Anderson, Law, \& Quale, 2009). Effective adoption and integration of ICT into the administration of schools depends mainly on the availability and accessibility of ICT resources such as hardware, software. If school administrators cannot access ICT resources, then they will not use them. This finding agrees with a study by Langat (2015) who found that access to technological resources is one of the effective facilitators of ICT usage in school administration. Further, a study by Afshari., Bakar., Luan., Samah and Fooi (2009)) among 814 faculty members in higher education in Turkey showed that majority of the respondents reported access to computers and the internet as a major factor for effective ICT usage. Also, a quantitative study conducted by Peralta and Costa (2007) to collect evidence from high school English teachers' views on computer attributes, cultural perceptions, computer competence, computer access, and personal characteristics revealed access to ICT was very important in effective school administration. This finding further agrees with Kiptalam and Rodrigues (2010) who examined the levels of access and extent of use of Information and Communication Technologies among teachers in selected Kenyan secondary schools. The study reported limited access to computers, laptops, projectors, printers and e-blackboards which affected effective utilization of ICT. Muthanga and Odipo (2018) also showed that computers were very few in Kenyan schools and the ones available lacked adequate software programmes.

\section{Conclusions}

The study established that ICT utilization greatly influences effective administration of secondary schools in Mitooma district of Uganda. Several factors contributed to underutilization of information communication technologies in the administration of secondary schools in Mitooma district. These include; lack of knowledge and skills of ICT, limited electricity supply, poor quality computers and limited computer accessories. 


\section{Recommendations}

To prevent underutilization of ICT in secondary schools in Mitooma District, the study recommends that the Ministry of Education and Sports should organize training sessions and workshops for all schoolteachers and administrators on ICT applications for management of their schools.

The Ministry of Education and Sports should also avail teachers and headteachers with portable battery-powered ICTs such as tablets and laptops instead of desktop computers that must be tethered to constant electricity supply. This will improve access, practice, and usage of ICT. To solve limited electricity supply, the study recommends that secondary schools in Mitooma district should transition to solar power which is very efficient and more cost-effective. The study also recommends that teachers and school administrators should have a positive attitude towards ICT.

\section{References}

Adedeji, T, (2011) Availability and use of ICT in South -Western Nigeria colleges of education. International Multidisciplinary Journal, 5(5), 315- 331.

Asiimwe, P., \& Byensi, L. (2017). The Influence Of Information And Communication Technology On Learning Among Secondary Schools In Developing Countries in Africa: Case Study Uganda-Mitooma: Secondary Schools. ResearchGate, Access: https://www.researchgate.net/publication/318851582, February 318851511, 318852019.

Afshari, M, Bakar K.A, Luan, W.S, Samah, B.A, \& Fooi, F.S ,(2009) Factors Affecting Teachers' Use Of Information And Communication Technology. International Journal of Instruction. 2(1), 77-104

Bostrom, R. P., \& Heinen, J. S., (1977). MIS problems and failures: A socio-technical perspective, MIS Quarterly, Vol. 1, No. 3, pp. 17-32 https://is.theorizeit.org/wiki/Sociotechnical_theory

District Education Department of Mitooma District. (2019). District Council Report. Mitooma. 
Egomo, J. E, Enyi, B.I, \& Tah, M.M, (2012) Availability and Utilization Of ICT Tools for Effective Instructional Delivery in Tertiary InstitutionsiIn Cross River State, Nigeria. Global Advanced Research Journal of Educational Research And Review. 1(8), 190-195

Freeman, I., \& Hasnaoui, A. (2010). Information and Communication Technologies (ICT): A tool to implement and drive corporate social responsibility (CSR) https://hal.archives-ouvertes.fr/hal00495968/document

Gupta, B., Dasgupta, S., \& Gupta, A. (2008). Adoption of ICT in a government organization in a developing country: An empirical study. The Journal of Strategic Information Systems, 17(2), 140-154.

Kayiwa S. J., D., Raihan, M. A., \& Clement, C. K. (2016). Role of ICT in Higher Educational Administration in Uganda. World Journal of Educational Research, 3(1) 1-10

G. K Kiptalam, \& A.J Rodrigues (2010). Accessibility and Utilization of ICT among Secondary School Teachers in Kenya. Strengthening the Role of ICT in Development. Makerere $\begin{array}{lllll}\text { University } & \text { Retrieved } & \text { on } & \text { June } & \text { from }\end{array}$ https://www.cit.mak.ac.ug/iccir/downloads/ICCIR_10/KIPTALAM_\%20\%20G.\%2 0K_\%20Rodrigues_\%20A.J_10.pdf

Kombo, D., \& Tromp, D. L. A. (2006). Proposal and Thesis Writing. Nairobi: Paulines Publications Africa.

Langat, A.C, (2015) Barriers Hindering Implementation, Innovation and Adoption of ICT in Primary Schools in Kenya. International Journal of Innovative Research and Development. $4(2)$.

Montoya, M. M., Massey, A. P., \& Lockwood, N. S. (2011). 3D collaborative virtual environments: Exploring the link between collaborative behaviors and team performance. Decision Sciences, 42(2), 451-476.

Muthanga, R. W., \& Odipo, M. (2018). The Effect of Accounting Practices on Management of Funds in Public Secondary Schools in Nairobi County. African Development Finance Journal (ADFJ), 1(2). 
Muyinda, P. B., Mayende, G., Maiga, G., \& Oyo, B. (2019). Widely Acclaimed but Lowly Utilized: Congruencing ODL Utilization with its Wide Acclaim. Universal Journal of Educational Research, 7(2), 400-412.

Nassaji, H. (2015). Qualitative and descriptive research: Data type versus data analysis: Sage Publications Sage UK: London, England.

Ngwu, O. G, (2014) Assessment of Availability and Utilization of ICT Resources in Teaching in F.C. E Eha-Amufu Enugu Nigeria. The International Conference on E-Learning in the Workplace, Retrieved on 16th June 2020 from https://www.icelw.org/proceedings/2014/ICELW2014/papers/Ngwu.pdf

Özdemir, S., İra, N., Arslan, H., \& Geçer, A. (2014). Validity And Reliability Study Of The Scale Of Managerial Effectiveness. Research on Education, 57.

Peralta, H., Costa, F.A. (2007). Teachers' Competence and Confidence Regarding the Use of ICT. Educational Sciences Journal (3) 75-84

Plomp, T., Anderson, R. E., Law, N., \& Quale, A. (2009). Cross-National Information and Communication Technology: Policies and Practices in Education. Charlotte, N.C.: Information Age Publishing.

Sharma, M. (2019). A Study of Information Communication Technology for Inclusive Education In Secondary Schools of Delhi. Unpublished research report retrieved from https://cutt.ly/ItKGB5f

Shafika, I, (2007) Survey of ICT and Education in Africa: Zimbabwe Country Report

Zimbabwe - www.infodev.org retrieved on 16th June 2020 from https://openknowledge.worldbank.org/handle/10986/10699

Tashakkori, A., \& Creswell, J., W. (2009). Exploring the Nature of Research Questions in Mixed Methods Research. Journal of Mixed Methods Research 23(3), 207-211. doi: 10.1177/1558689807302814.

Walker, G. H., Stanton, N. A., Salmon, P., \& Jenkins, D. P. (2008). A review of sociotechnical systems theory: A classic Concept for New Command and Control Paradigms. Theoretical Issues in Ergonomics Science, 9(6), 479-499. https://doi.org/10.1080/14639220701635470 